\section{Response of Seashore Dropseed and Weed Species to the Preemergence Herbicide Oxadiazon Applied as a Component of a Hydromulch Cap}

\author{
Scott B. Lukas ${ }^{1,3}$, Joseph DeFrank ${ }^{1}$, Orville C. Baldos ${ }^{1}$, \\ and Glenn S. Sakamoto ${ }^{2}$
}

ADDITIONAL INDEX WORDs. revegetation, native, grass, Hawaii, Sporobolus virginicus

Summary. In Hawaii, seashore dropseed (Sporobolus virginicus), a coastal native grass, has been identified as a useful species for roadside revegetation. Cuttings of seashore dropseed covered with a hydromulch cap, irrigated, and managed to control weeds have greater establishment success. In this study, the efficacy and phytotoxicity of the preemergence herbicide oxadiazon applied as a component of the hydromulch cap over seashore dropseed cut stems was evaluated. Oxadiazon in two formulations, granule and suspension concentrate (SC), was applied at two rates of 2.0 and $4.0 \mathrm{lb} / \mathrm{acre}$, resulting in four chemical treatments. Seashore dropseed response was recorded as numerical counts of new shoots, aboveground biomass, and percent visual coverage. The highest new shoot counts of seashore dropseed, aboveground biomass, and visual canopy coverage were recorded in plots treated with the granular $(G)$ formulation of oxadiazon applied at $2.0 \mathrm{lb} /$ acre. All hydromulch cap treatments containing herbicides reduced weed pressure compared with the untreated control treatment. Granular oxadiazon at $2.0 \mathrm{lb} /$ acre in the hydromulch cap provided commercially acceptable weed control while maintaining high levels of rooting and plant vigor during the establishment period.

$\mathrm{T}$ he ecological effects of roads impact nearly $15 \%$ of the land area of the United States, an area equivalent in size to all conservation areas of the country combined (Wilkinson et al., 2008). Planting roadsides with native species can displace nonnative or potentially noxious plant species (Landis et al., 2005). Weed control may be essential for the long-term survival of native species when developing reliable and efficient roadside establishment protocols. Seashore dropseed is a perennial, coastal salt marsh grass that spreads by rhizomes, forming extensive colonies, and has potential as a low-maintenance groundcover in saline areas (Marcum and Murdoch, 1992). In Hawaii, seashore dropseed is typically found in low-lying areas

This paper is a portion of a Master's thesis submitted by Scott B. Lukas at the University of Hawaii at Manoa.

We would like to thank the Hawaii Department of Transportation for providing funding for this research.

${ }^{1}$ Department of Tropical Plant and Soil Sciences, University of Hawaii at Manoa, St. John Plant Science Lab 102, 3190 Maile Way, Honolulu, HI 96822

${ }^{2}$ U.S. Department of Agriculture, Hoolehua Plant Materials Center, 4101 Maunaloa Highway, P.O. Box 236, Hoolehua, HI 96729

${ }^{3}$ Corresponding author. E-mail: slukas@hawaii.edu. with an abundant source of subsurface water. The potential of seashore dropseed to establish and thrive in high-saline soils is a valuable attribute in coastal restoration (Ashour et al., 1997; Semple et al., 2006).

Seashore dropseed produces very few viable seeds requiring vegetative propagation for large-scale plantings. Vegetative propagation of seashore dropseed using terminal stem cuttings is preferred to harvesting rhizomes that severely disrupt stock bed root systems. Harvesting terminal stem cuttings also promotes vigorous growth in the stock plant and ensures a regular yield of planting material (Baldos, 2009). Improved rooting of seashore dropseed stem cuttings is obtained after a 24-h soak in a rooting hormone (Baldos, 2009).

The potential for excessive erosion from roadside areas is greatest after setting the finished grade and before establishment of permanent vegetative cover (Holt et al., 2005). The erosion hazard can be reduced by hydroseeding or hydromulching (Babcock and Mclaughlin, 2013). Hydromulch caps can be customized with various materials to suit specific vegetation needs. Hydromulch is a water-based slurry of shredded paper, fine straw, and a tackifier, designed to adhere plant material to the ground and provide a protective top layer. In Hawaii, seashore dropseed is slow to establish ( $>3$ months) from cuttings and provide a weedsuppressing canopy. Preemergence herbicides can greatly increase the success of native plant establishment (Tjelmeland et al., 2008). Established native species resist weed invasion (Borman et al., 1991), and use resources efficiently, leaving fewer resources available for weed recruitment (Herron et al., 2001). Baldos et al. (2010) determined that excellent weed control could be obtained during field establishment with seashore dropseed plugs with the use of spray applications of oxadiazon (4.0 lb/acre) (Baldos et al., 2010). The objective of this groundcover establishment study was to evaluate the response of weeds and cut stems of seashore dropseed to two rates and two formulations of oxadiazon, incorporated into a hydromulch cap.

\section{Materials and methods}

Plant material. Seashore dropseed [U.S. Department of Agriculture (USDA) plant accession HA-4840/ ACC. \# 9079840] stock plants were grown in-ground at the USDA Natural Resource Conservation Service

\begin{tabular}{llll}
\hline $\begin{array}{l}\text { Units } \\
\begin{array}{l}\text { To convert U.S. to SI, } \\
\text { multiply by }\end{array}\end{array}$ & U.S. unit & SI unit & $\begin{array}{l}\text { To convert SI to U.S., } \\
\text { multiply by }\end{array}$ \\
\hline 0.3048 & $\mathrm{ft}$ & $\mathrm{m}$ & 3.2808 \\
0.0929 & $\mathrm{ft}^{2}$ & $\mathrm{~m}^{2}$ & 10.7639 \\
3.7854 & $\mathrm{gal}$ & $\mathrm{L}$ & 0.2642 \\
9.3540 & gal/acre & $\mathrm{L} \cdot \mathrm{ha}^{-1}$ & 0.1069 \\
2.54 & inch $(\mathrm{es})$ & $\mathrm{cm}$ & 0.3937 \\
25.4 & inch $(\mathrm{es})$ & $\mathrm{mm}$ & 0.0394 \\
0.4536 & $\mathrm{lb}$ & $\mathrm{kg}$ & 2.2046 \\
1.1209 & $\mathrm{lb} / \mathrm{acre}$ & $\mathrm{kg} \cdot \mathrm{ha}^{-1}$ & 0.8922 \\
28.3495 & $\mathrm{Oz}$ & $\mathrm{g}$ & 0.0353 \\
305.1517 & $\mathrm{Oz} / \mathrm{ft}^{2}$ & $\mathrm{~g} \cdot \mathrm{m}^{-2}$ & 0.0033 \\
1 & $\mathrm{ppm}$ & $\mathrm{mg} \cdot \mathrm{L}^{-1}$ & 1 \\
$\left({ }^{\circ} \mathrm{F}-32\right) \div 1.8$ & ${ }^{\circ} \mathrm{F}$ & ${ }^{\circ} \mathrm{C}$ & $\left({ }^{\circ} \mathrm{C} \times 1.8\right)+32$
\end{tabular}


(NRCS) Hoolehua Plant Materials Center (PMC), located in Hawaii on the island of Molokai. The original collection location site of this accession was from Moomomi, Molokai.

EXPERIMENTAL PLAN. The experiments were conducted at the USDANRCS Hoolehua PMC on Molokai, in 2009 and 2010. In 2010, the experiment was located in a field adjacent to the one used in the 2009 experiment. The soil type in both trials was a Holomua series soil (silt loam, typic eutrotorrox). The experimental design was a randomized complete block with five treatments replicated four times, blocks were arranged along the vector of the prevailing northeasterly winds. The treatments included oxadiazon in two formulations, G and SC (Ronstar $\mathrm{G}$ and SC; Bayer CropScience, Research Triangle Park, NC) with two rates of application $(2.0$ and $4.0 \mathrm{lb} /$ acre a.i.) and untreated. Plot size was $15-\mathrm{ft}$ long and 6-ft wide. Fertilization and irrigation regimes were standardized between 2009 and 2010 experiments.

MET EOROLOGICAL AND IRRIGATION DATA. Irrigation was delivered at a rate of $2250 \mathrm{~L} \cdot \mathrm{ha}^{-1} \cdot \mathrm{min}^{-1}$. During the first $5 \mathrm{~d}$ of both experiments, overhead irrigation was delivered for 15 min every $2 \mathrm{~h}$ between 7:00 AM and 5:00 PM. During the evening, irrigation was delivered for 5 min every 4 h between 7:00 PM and 3:00 AM. After $5 \mathrm{~d}$, the daytime irrigation start times were reduced to 10 min and all of the night watering cycles were stopped. At $35 \mathrm{~d}$ after planting (DAP), all irrigation times remaining during the day cycle were reduced to 8 min per cycle.

Meteorological data were collected from the USDA-NRCS research station. The mean ambient daily temperature for the duration of the first trial in 2009 was $24.6^{\circ} \mathrm{C}$, compared with the mean ambient temperature of the second trial of $24.0^{\circ} \mathrm{C}$. Natural mean rainfall throughout the duration of the first experiment was $25.4 \mathrm{~mm}$ compared with $26.3 \mathrm{~mm}$ in the second experiment.

VEGETATIVE MATERIAL HANDLING. The seashore dropseed plant material was harvested from the USDA-NRCS Hoolehua PMC stock beds by removing uniform aboveground shoots $\approx 40-60 \mathrm{~cm}$ long. Before planting, vegetative cuttings $(40-60 \mathrm{~cm})$ from mature plants were soaked for $24 \mathrm{~h}$ in a solution of rooting hormone [275 ppm indole-3-butyric acid $(\mathrm{IBA})+137.5 \mathrm{ppm}$ l-napthaleneacetic acid (NAA) (Dip'N Grow; Dip'N Grow, Clackamas, OR)]. After the soaking period, $0.7 \mathrm{~kg}$ of fresh stems $\left(1200 \mathrm{~kg} \cdot \mathrm{ha}^{-1}\right)$ were evenly distributed on the soil surface across the center portion $(4 \times 15 \mathrm{ft})$ of each plot. Stems were spread to ensure complete contact with the soil but were not pressed or rolled.

HYDROMULCH MATERIAL. Hydromulch is a blend of shredded paper, fine straw, and a tackifier, which is intended to adhere plant material to the soil surface while providing a protective covering. The hydromulch cap was applied at a rate of $62,700 \mathrm{~L} \cdot \mathrm{ha}^{-1}$. The hydrocap treatments were prepared in 80 gal batches based on research conducted by Baldos in 2009, that contained: $5.7 \mathrm{~kg}$ paper mulch (Nature's Own Organic; Hamilton Manufacturing, Twin Falls, ID), $5.2 \mathrm{~kg}$ processed straw mulch (Hydrostraw; HydroStraw, Manteno, IL), $54 \mathrm{~g}$ tackifier (C:Tac; Hamilton Manufacturing, Twin Falls, ID) and $124 \mathrm{~g}$ fertilizer $(22 \mathrm{~N}-0.87 \mathrm{P}-$ $7.5 \mathrm{~K})$ to obtain a rate of $50 \mathrm{lb} /$ acre $\mathrm{N}$ (Lesco Turf Fertilizer; Lesco, Cleveland, $\mathrm{OH})$. Herbicides were added to the hydrocap solution to obtain low and high label application rates of oxadiazon of 2.0 and $4.0 \mathrm{lb} /$ acre. Each experimental unit was treated with $17.5 \mathrm{gal}$ of hydromulch cap applied with a gasoline motor powered hydromulching system (HS-100-M; Turbo Technologies, Beaver Falls, PA), using a hose fitted with a fan nozzle.

Data collection. The weed pressure and establishment indicators of seashore dropseed were evaluated two times during each of the experiments. In 2009, at $47 \mathrm{DAP}$, counts of new green growing apical tips of seashore dropseed (in $\mathrm{l} \mathrm{m}^{2}$ ) and timed hand weeding to remove all weeds from the entire plot were recorded. Hand weeding provided a measure of weed pressure as well as eliminating future weed competition on seashore dropseed to allow for a more accurate representation of herbicide phytotoxic effects. After data were collected at this date, $100 \mathrm{lb} /$ acre $\mathrm{N}$, in a formulation of $22 \mathrm{~N}-0.87 \mathrm{P}-7.5 \mathrm{~K}$ fertilizer, was applied to the entire experiment. At 110 DAP, a visual rating of seashore dropseed percent coverage of experimental plots and the aboveground dry weight accumulation (in $\mathrm{l} \mathrm{m}^{2}$ ) were recorded. Stems were hand cut at soil surface and dried for each treatment. Fresh plant material was dried at $67^{\circ} \mathrm{C}$ until weights stabilized before recording dry plant weight, $\approx 4 \mathrm{~d}$.

In 2010 , the same weed control and groundcover growth measures were collected at 77 DAP (shoot counts and timed weeding) and 126 DAP (seashore dropseed percent groundcover and biomass accumulation).

Data analysis. All data were subjected to an analysis of variance (ANOVA) using a statistical software package (Statistix ${ }^{\top \mathrm{TM}}$ 10; Analytical Software; Tallahassee, FL). The data were analyzed as a split plot with years as the main plot and treatments as sub plot. Means were separated using Fisher's protected least significant difference (LSD) test at $\alpha=0.05$. When significant year by treatment interactions were detected, years were presented separately, otherwise data for each year were combined. Timed weeding data to return the plots to a weed free status in both years were $\log$ transformed to meet assumptions of normality of the ANOVA (Bartlett, 1947; Hoshmand, 1994).

\section{Results and discussion}

Timed HAND weEding. Results of the analysis for the time to return the plots to a weed-free status indicated an interaction of year and treatment $(P<0.001)$, therefore results are presented by year (Table 1 ). In 2009, weeding times for untreated plots were longer than those treated with oxadiazon. The $\mathrm{G}$ formulation of oxadiazon at $2.0 \mathrm{lb} /$ acre provided less weed control than the high rate of G oxadiazon and both rates of the SC. The four predominant weeds present during this period were slender amaranth (Amaranthus viridus), panama crowngrass (Paspalum fimbriatum), cupid's-shaving brush (Emilia fosbergii), and goosegrass (Eleusine ind$i c a)$. In 2010, weeding times in untreated plots were longer than all of the chemical treatments, there were no differences within herbicide treatments. The four predominant weeds present during the 2010 experiment were tufted lovegrass (Eragrostis pectinacea), slender amaranth, goosegrass, and garden spurge (Chamaesyce hirta). Weed species differed over years because of the natural fluctuations of weed recruitment over time and the alternate field site. 
Table 1. Weeding times and seashore dropseed growth response to establishment success with oxadiazon at two rates (2.0 and $4.0 \mathrm{lb} / \mathrm{acre})$ and two formulations $(\mathrm{G}=$ granular and $\mathrm{SC}=$ suspension concentrate $)$ as a component of a hydromulch cap. Means are reported from four experimental replications.

\begin{tabular}{|c|c|c|c|c|c|c|c|c|}
\hline \multirow{2}{*}{\multicolumn{2}{|c|}{ Treatment }} & \multirow{2}{*}{\multicolumn{2}{|c|}{$\begin{array}{l}\text { Weed control } \\
\text { Weeding time } \\
\left(\mathrm{s} / 90 \mathrm{ft}^{2}\right)^{\mathrm{z}}\end{array}$}} & \multicolumn{5}{|c|}{ Seashore dropseed establishment success } \\
\hline & & & & \multicolumn{2}{|c|}{$\begin{array}{l}\text { Shoot counts } \\
\left(\text { no. } / \mathrm{m}^{2}\right)^{\mathrm{z}}\end{array}$} & \multicolumn{2}{|c|}{$\begin{array}{c}\text { Visual } \\
\text { cover }(\%)\end{array}$} & \multirow{2}{*}{$\begin{array}{c}\begin{array}{c}\text { Dry biomass } \\
\left(\mathrm{g} \cdot \mathrm{m}^{-2}\right)^{\mathrm{z}}\end{array} \\
-\end{array}$} \\
\hline Formulation & Rate $(\mathrm{lb} / \text { acre })^{\mathrm{z}}$ & 2009 & 2010 & 2009 & 2010 & 2009 & 2010 & \\
\hline \multirow[t]{2}{*}{ G } & 2.0 & $104 b^{y}$ & $129 \mathrm{~b}$ & $262 \mathrm{~cd}$ & $429 \mathrm{ab}$ & $80 \mathrm{ab}$ & $88 \mathrm{a}$ & 325 a \\
\hline & 4.0 & $40 \mathrm{c}$ & $123 \mathrm{~b}$ & 209 cde & 458 a & $71 \mathrm{abc}$ & $67 \mathrm{bcd}$ & $179 \mathrm{~b}$ \\
\hline SC & 2.0 & $33 \mathrm{c}$ & $170 \mathrm{~b}$ & $167 \mathrm{de}$ & $265 \mathrm{~cd}$ & $68 \mathrm{abcd}$ & $50 \mathrm{~d}$ & $152 \mathrm{~b}$ \\
\hline
\end{tabular}

${ }^{\mathrm{z}} \mathrm{l} \mathrm{lb} / \mathrm{acre}=1.1209 \mathrm{~kg} \cdot \mathrm{ha}^{-1} \mathrm{l} ; \mathrm{l} \mathrm{s} / 90 \mathrm{ft}^{2}=0.1196 \mathrm{~s} \cdot \mathrm{m}^{-2} ; \mathrm{l}$ shoot $/ \mathrm{m}^{2}=0.0929$ shoot $/ \mathrm{ft}^{2} ; 1 \mathrm{~g} \mathrm{~m}^{2}=0.0033 \mathrm{oz} / \mathrm{ft}^{2}$.

${ }^{y}$ Means within a column followed by the same letter are not significantly different according to Fisher's protected least significant difference (LSD) test at $\alpha=0.05$.

New apical shoot counts. The results of the analysis indicated an interaction between the effects of year and treatment $(P=0.007)$, therefore results are presented by year (Table 1 ). In 2009 , there were no differences within the treatments for new shoot counts. In 2010, new growing shoot counts in herbicide-treated plots were higher than counts in untreated plots. The highest shoot count in 2010 was recorded in plots treated with the G formulation of oxadiazon applied at $4.0 \mathrm{lb} /$ acre.

Percent visual cover. The results of the analysis indicated an interaction between the effects of year and treatment $(P=0.0003)$, therefore results are presented by year (Table 1 ). In both years, the highest level of percent cover was recorded in plots treated with the $G$ formulation of oxadiazon at $2.0 \mathrm{lb} /$ acre. In 2009 , there was no difference in percent cover among untreated plots and plots with the $\mathrm{G}$ formulation of oxadiazon at 4.0 $\mathrm{lb} / \mathrm{acre}$ and plots treated with SC formulation. In 2010, weed pressure in untreated plots resulted in a complete loss of seashore dropseed cover due to competition. The highest visual coverage in 2010 was recorded with the G formulation of oxadiazon applied at $2.0 \mathrm{lb} /$ acre.

SEASHORE DROPSEED DRY ABOVEGROUND BIOMASS. The results of the analysis indicated no interaction between the effects of year and treatments $(P=0.12)$ allowing for the pooling of means over both years (Table 1). Biomass accumulation in herbicide treated plots was higher than the untreated plot. The highest level of biomass accumulation was recorded in plots treated with the $\mathrm{G}$ formulation of oxadiazon at $2.0 \mathrm{lb} /$ acre.
Weed control and seashore dropseed growth were significantly affected by applying oxadiazon as a component of the hydromulch cap at time of planting. Weeding times were greatly reduced when oxadiazon was incorporated into the hydromulch cap with no clear differences between the G and SC formulations. Growth measures of seashore dropseed were improved when oxadiazon was incorporated into the hydromulch cap with the greatest growth recorded in plots treated with the $G$ formulation. The $\mathrm{G}$ formulation of oxadiazon applied at $2.0 \mathrm{lb} /$ acre provided the highest level of biomass accumulation of seashore dropseed that we attributed to an extended period of weed control, which reduced weed competition and lowest level of chemical inhibition of crop growth. Longer periods of effective weed control have been reported for $G$ formulations of oxadiazon due to an extended release period from the granule carrier (Johnson et al., 1989). Greater crop phytotoxicity was recorded in the SC formulation, which was attributed to the direct initial exposure to the chemical, compared with the extended release from the granule formulation.

In conclusion, the results reported here support the use of G oxadiazon in the hydromulch cap for weed control during the establishment of seashore dropseed from stem cuttings. We observed that optimum rooting and growth of cut stems was achieved when all plant materials were applied in such a way as to ensure good contact with moist soil. Stems that were piled on top of each other or protruding upright were observed to either dry out or failed to produce roots. Irrigation levels should be maintained so that the ground remains wet but not to the point of runoff during the initial rooting period. Once seashore dropseed is well rooted, irrigation levels can be reduced. After the first cycle of hand weeding, fertilizer and additional applications of $\mathrm{G}$ oxadiazon can be applied to maintain weed control and maximize growth to reduce the time required for canopy closure.

In future research, it would be beneficial to expand the reported establishment protocol to different species. By creating a streamlined establishment protocol factoring weed competition as outlined in this research can be a valuable tool for restoration practitioners.

\section{Literature cited}

Ashour, N.I., M.S. Serag, A.K.A. ElHaleem, and B.B. Mekki. 1997. Forage production from three grass species under saline irrigation in Egypt. J. Arid Environ. 37:299-307.

Babcock, D.L. and R.A. McLaughlin. 2013. Erosion control effectiveness of straw, hydromulch, and polyacrylamide in a rainfall simulator. J. Soil Water Conserv. 68:221-227.

Baldos, O. 2009. Assessment of hydroplanting techniques and herbicide tolerance of two native Hawaiian groundcovers with roadside revegetation potential. MS. Thesis, Univ. Hawaii at Manoa, Honolulu.

Baldos, O.C., J. DeFrank, and G. Sakamoto. 2010. Tolerance of transplanted seashore dropseed to pre and postemergence herbicides. Hort Technology 20:772-777.

Bartlett, M.S. 1947. The use of transformations. Biometrics 3:39-52.

Borman, M.M., W.C. Krueger, and D.E. Johnson. 1991. Effects of established 


\section{Preliminary and Regional Reports}

perennial grasses on yields of associated annual weeds. J. Range Mgt. 44:318322.

Herron, G.J., R.L. Sheley, B.D. Maxwell, and J.S. Jacobsen. 2001. Influence of nutrient availability on the interaction between spotted knapweed and bluebunch wheatgrass. Restor. Ecol. 9:326-331.

Holt, G., M. Buser, D. Harmel, K. Potter, and M. Pelletier. 2005. Comparison of cotton based hydromulches and conventional wood and paper hydromulches Study 1. J. Cotton Sci. 9:121-127.

Hoshmand, A.R. 1994. Experimental research design and analysis: A practical approach for agricultural and natural sciences. CRC Press, Boca Raton, FL.

Johnson, M.D., D.L. Wyse, and W.E. Lueschen. 1989. The influence of herbicide formulation on weed control in four tillage systems. Weed Sci. 37:239-249.

Landis, T.D., K.M. Wilkinson, D.E. Steinfeld, S.A. Riley, and G.N. Fekaris. 2005. Roadside revegetation of forest highways: New applications for native plants. Native Plants J. 6:297-305.

Marcum, K.B. and C.L. Murdoch. 1992. Salt tolerance of the coastal salt marsh grass, Sporobolus virginicus (L.) kunth. New Phytol. 120:281-288.
Semple, W.S., I.A. Cole, T.B. Koen, D. Costello, and D. Stringer. 2006. Native couch grasses for revegetating severely salinised sites on the inland slopes of NSW. Part 2. Rangeland J. 28:163-173.

Tjelmeland, A.D., J. Lloyd-Reilley, and T.E. Fulbright. 2008. Evaluation of herbicides for restoring native grasses in buffelgrass dominated grasslands. Restor. Ecol. 16:263-269.

Wilkinson, K.M., T.D. Landis, D.E. Steinfeld, and S.A. Riley. 2008. Native plants on disturbed roadsides: Introduction to a new integrated approach. Native Plants J. 9:267-277. 